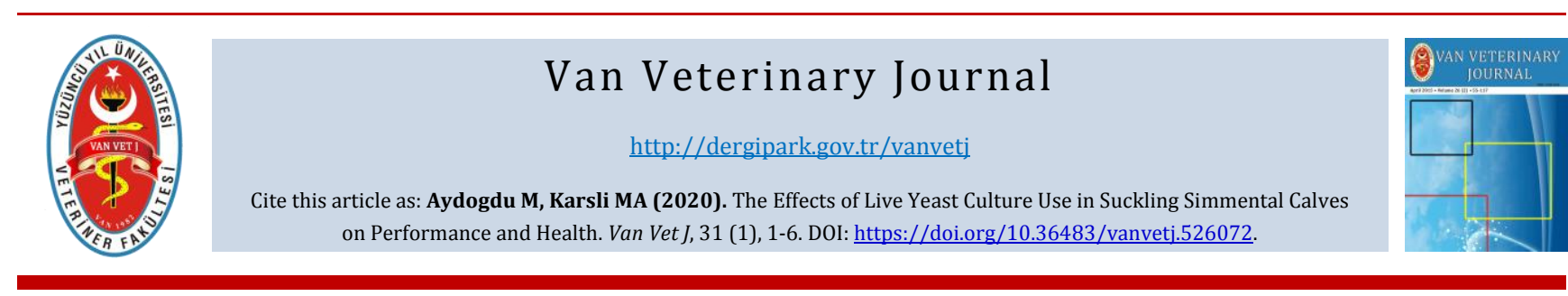

\title{
The Effects of Live Yeast Culture Use in Suckling Simmental Calves on Performance and Health
}

\author{
Mustafa AYDOĞDU ${ }^{*}{ }^{*} \quad$ M. Akif KARSLI ${ }^{2}(\mathbb{0}$ \\ ${ }^{1}$ Corum Food, Agriculture and Livestock Provincial Directorate, Corum, Turkey \\ ${ }^{2}$ Kirikkkale University, Faculty of Veterinary Medicine, Department of Animal Nutrition and Nutritional Disease, Kırıkkale, Turkey
}

Received: 12.02 .2019

Accepted: 04.12.2019

\begin{abstract}
The aim of this study was to evaluate the effects of live yeast culture (Saccharomyces cerevisiae) on calf live weight gain, daily live weight gain, fed intake, feed efficiency and health. Three groups were created by using calf fed starter diet without live yeast culture (Control group=C), with $5 \mathrm{gr} /$ calf/day live yeast culture (Low dose live yeast culture =LDLYC) or $10 \mathrm{gr} /$ calf/day live yeast culture (High dose live yeast culture =HDLYC). Blood samples were withdrawn from each calves at the end of experiment. Average birth weights of calves were $41.58,42.42,41.17 \mathrm{~kg}$ whereas average weaning live weights were $81.50,84.58$, and $85.58 \mathrm{~kg}$ for $\mathrm{C}$, LDLYC and HDLYC, respectively. Daily live weight gains and total amount of weight gained during experiment were $0.67,0.70$, and $0.74 \mathrm{~kg} / \mathrm{d}$; and 39.92, 42.17, $44.42 \mathrm{~kg}$ for C, LDLYC and HDLYC, respectively. Mean daily feed intakes were 282.26, 300.65, and $254.01 \mathrm{gr} / \mathrm{d}$ for C, LDLYC and HDLYC, respectively. Mean feed efficiency values were $418.89,419.44$, and 342.93 gr feed/kg daily weight gain for C, LDLYC and HDLYC, respectively. Percentage of calves that had diarrhea during experiment was $83.33,66.67$ and $33.33 \%$ for $\mathrm{C}$, LDLYC and HDLYC, respectively. While the percentages of lymphocyte $(\mathrm{P}=0.06)$ linearly decreased the percentage of neutrophil $(\mathrm{P}=0.05)$ linearly increased with increasing levels of live yeast culture. In conclusion, it was thought that even though it was not statistically significant, addition of live yeast culture improved live weight gain, feed efficiency, and calf health and may have positive effect on immunity.
\end{abstract}

Keywords: Live Yeast Culture, Suckling Calf, Live Weight Gain, Feed Efficiency

ÖZ

\section{Canlı Maya Kültürü Kullanmanın Süt Emen Simental Buzağılarda Performans ve Sağlık Üzerine Etkileri}

Bu çalışmada canlı maya kültürünün buzağıların canlı ağırlık, canlı ağırlık artışı, yem tüketimi, yemden yaralanma ve sağlığı üzerine etkilerini değerlendirmek amaçlanmıştır. Katkısız ticari buzağı başlangıç yemi (K=Kontrol), ticari buzağı başlangıç yemine ile $5 \mathrm{gr} /$ buzağı/gün (DCMK=Düşük Canlı Maya Kültürü) ve 10 gr/buzağı/gün (YCMK=Yüksek Canlı Maya Kültürü) canlı maya kültürü tüketen buzağı gruplarından oluşan 3 grup oluşturulmuştur. Çalışmanın sonunda bütün buzağılardan kan alınmıștır. Doğum ağırlıkları K, DCMK, YCMK sırasıyla; 41.58, 42.42, $41.17 \mathrm{~kg}$, sütten kesme ağırlıkları ise aynı sırayla 81.50, 84.58, $85.58 \mathrm{~kg}$ olarak ölçülmüştür. Canlı ağırlık artışları değerlendirildiğinde DCMK, YCMK ve K için; 0.70, 0.74 ve $0.67 \mathrm{~kg} / \mathrm{gün}$, toplam canlı ağırlık artışı ise aynı sırayla 42.17, YCMK 44.42 ve kg $39.92 \mathrm{~kg}$ olarak belirlenmiștir. Deneme süresince DCMK 18039.17 gr, YCMK 15240.83 gr ve K 16935.83 gr yem tüketmişlerdir. Ortalama günlük tüketimleri ise DCMK 300.65 gr/gün, YCMK 254.01 gr/gün ve kg 282.26 gr/gün olarak hesaplanmıștır. Yemden yararlanma değerleri ise DCMK 419.44 gr yem/kg ağırlık artışı, YCMK 342.93 gr yem/kg canlı ağırlık artışı ve K 418.89 gr yem/kg ağırlık artıșı olarak hesaplanmıștır. Deneme süreci boyunca buzağılarda isal görülme oranı DCMK de \%66.67, YCMK de \%33.33 ve $\mathrm{K}$ da ise \%83.3 olarak tespit edilmiştir. Kan hücrelerinden lenfosit oranı katılan kattı oranına paralel olarak azalıkken nötrofil oranının $(\mathrm{P}=0.05)$ ise lineer olarak artış gösterdiği saptanmıştır. Sonuç olarak, süt buzağılarına verilen mayanın istatistiksel olarak olmasa da canlı ağırlık artışı, yemden yaralanmayı, buzağı sağlığını iyileştirdiği ve immum sistem üzerine de olumlu etkisi olabileceği kanaati oluşmuştur.

Anahtar Kelimeler: Canlı Maya Kültürü, Süt Buzağısı, Canlı Ağırlık Artışı, Yemden Yararlanma 


\section{GíRIŞ}

Sürülerdeki temel ve en önemli sınırlandırıcı etken doğum sonrası buzağı mortaliteleridir. Dünya çapında, neonatal buzağı mortalite oranları \%8.7'den \%67'ye kadar değişkenlik gösterir. İlk aylarda görülen neonatal buzağ mortalitesi, toplam mortalite oranlarının \%84'ünü oluşturur ve özellikle buzağıların yaşamının üçüncü haftalarında görülme oranı yüksektir. Bazı araștırmacılara göre; buzağılarda ve manda yavrularında görülen mortalite oranları \%29.1 ile \%39.8 arası değișir. Ayrıca, erken dönemdeki buzağı mortalitelerinin ortalama $\% 25$ ' $\mathrm{i}$, düşük verimli hayvanlardan oluştuğundan, bu sırada kontrol amacıyla çeşitli uygulamalar yapılsa da, sürü sağlığında yapılması gereken prosedürler daha zordur (Anonim 2016).

Buzağı ölümleri gelişmiş ülkelerde \%2-3 civarında iken maalesef bu oran ülkemizde \%15 civarındadır. Yeni doğan buzağı ishalleri bütün dünyada yaygın olarak gözlemlenir, süt hayvancllığı ve besicilik yapılan işletmelerde önemli ekonomik kayıplara yol açmaktadır. Mortalite oranı gelișmiş Avrupa ülkelerinde \%10-15 arasında değişmekle birlikte, işletmeden işletmeye farklı oranlarda ortaya çıkarak, \%50'ye varan daha șiddetli kayıplar söz konusu olabileceği gibi, kayıp oranı \% 1-2 olan işletmelerde bulunabilir. Hastalığın problem olduğu çiftliklerde buzağıların \%100'ü hastalığa yakalanabilir. İsale bağlı buzağı kayıplarının ülkemiz içinde ciddi sorun olduğu bilinmektedir (Şahal ve ark. 2017).

Hayvansal üretimde kullanılan antibiyotiklerin, hayvansal ürünlerde kalıntı bıraktığı ve bu hayvansal ürünleri tüketen insanlarda bazı alerjik reaksiyonlara yol açtığı ve sonuçta insanlarda hastallk yapan bazı bakterilerin tedavide kullanılan antibiyotiklere direnç kazanmalarına yol açtığı yolundaki bazı bulgular; antibiyotiklere olan güvenin zayıflamasına yol açmıştır. Bununla beraber, sindirim sistemindeki patojen mikroorganizmalarla beraber bazı faydalı mikroorganizmaların da ölümüne neden olduğu bildirilmektedir. Tüketicilerin artan bilinç ve baskıları sonucu, antibiyotiklerin verim artırıcı olarak kullanılmasının insan ve hayvan sağlığı üzerindeki olumsuz etkileriyle ilgili bazı bulguların ardından ilk kez 1986 yılında İsveç'te büyütme faktörü amaçlı kullanımı yasaklanmış, daha sonra 01 Haziran 1999 yılında Avrupa Birliği'nde belirtilen amaçla kullanımlarına sınırlama getirilmiştir. Ülkemizde ise bu karar Tarım ve Köy İşleri Bakanlığı'nca alınmış ve 30 Eylül 1999'da antibiyotiklerin hayvan yemlerinde verim artırıcı olarak kullanılması yasaklanmıştır (Saygıcı ve Günal 200; Öztürk ve Yıldırım 2004).

Antibiyotiklerle ilgili bu yasal gelișmeler, oluşan boşluğun doldurulması için probiyotik, prebiyotik ve bitki extraktları gibi alternatif yem katkı maddelerini gündeme getirmiştir. Probiyotiker, mide-bağırsak flora ve faunasını düzenlemek, patojen mikroorganizmaların gelişimini engellemek ve yemden yararlanmayı artırmak gibi amaçlarla yeme toz, granül, sıvı süspansiyon, kapsül ve pelet formlarında karıştırılan ya da içme suyuna verilen canlı bakteri veya maya kültürleri içeren biyolojik ürünlerdir.

Bu çalışmamızda süt emme dönemindeki buzağılarda bir probiyotik olan canlı maya kültürü kullanımının buzağıların canlı ağırlık, canlı ağırlık artışı, yem tüketimi, yemden yaralanma ve sağlığı üzerine etkilerini değerlendirmek amaçlanmıştır.

\section{MATERYAL ve METOT}

Bu çalışmada, Çorum Merkez Ova Karapınar Köyünde bir Simental Irkı Damızlık Süt Sığırı işletmesinde yeni doğan buzağılardan doğum sırası ve cinsiyete göre seçilen 3 farklı grupta toplam 18 adet buzağının; Canlı Saccharomyces cerevisiae kültürü içeren Vimasacc ${ }^{\circledR}$ isimi ticari maya'nın buzağılarda canlı ağırlık artışı, yem tüketimi, yemden yararlanma ve sağlığı üzerine etkileri belirlenmeye çalışılmıștır. Hayvanlar doğumlarından itibaren doğum sırası ve cinsiyetine göre düşük doz canlı maya kültürü (DDG), yüksek doz canlı maya kültürü (YDG) ve kontrol grubu (KG) olmak üzere 3 gruba ayrılmıştır. Her bir gruba 3 dişi ve 3 erkek olmak üzere toplam 6 şar buzağ seçilmiştir. Kontrol grubu dahil denemeye alınan buzağı sayısı 18 baştır. Her bir buzağının doğumu takip eden ilk 2 saat içerisinde tartımı yapılarak doğum ağırlığı kaydedilip bireysel buzağı kulübelerine alınmıștır. Kulübelere alınırken Gıda Tarım ve Hayvancılık Bakanlığının plastik tanımlama küpesi ile küpelenerek numaraları kaydedilmiştir.

İlk üç gün kolostrum verildikten sonra 4. gün ile beraber düşük doz grubuna $5 \mathrm{gr} /$ gün, yüksek doz grubuna 10 gr/gün canlı maya kültürü süt içerisinde verilmeye başlanılmıștır. Kontrol grubuna ise her hangi bir katkı verilmemiștir. Denemede kullanılan canlı maya kültürü canlı $12 \times 10^{11} \mathrm{CFU} / \mathrm{kg}$ Saccharomyces cerevisiae kültürü ile taşıyıcı madde olarak kalsiyum karbonat ve kepek içerdiği garanti edilen ticari maya $25 \mathrm{~kg}$ 'lık açllmamış paket olarak temin edilmiştir. Bütün gruplarda bulunan hayvanlara verilen süt miktarları aynı miktarlarda ve 55. güne kadar iki öğün halinde, sağllan günlük sütten alınarak süt hazırlama makinesinde $38{ }^{\circ} \mathrm{C}$ 'de verilmiştir. Verilen günlük süt miktarı, hayvanların yaşı dikkate alınarak; 0-7 günler arası 2 lt/öğün, 8-28 günler arası 2,5 lt/öğün, 29-42 günler arası 3 lt/ögün, 43-49 günler arası 2,5 lt/ögün, 5053 günler arası 2 lt/ögün, 54-55 günler arası 1 lt tek ögün, 56. gün ise süt verilmemiştir. Yine sütten kesim stresini azaltmak amacı ile 57. gün arası $1 \mathrm{lt}$ tek öğün, 58. gün süt verilmemiş, 59. gün arası $1 \mathrm{lt}$ tek öğün süt verildikten sonra buzağılar 60 . günden itibaren sütten kesilmiştir. Süt besleme tablosu aşağıda belirtilmiştir. Sütle beslemeye ek olarak, su ve \% $18 \mathrm{HP}$ ve $2700 \mathrm{kcal} / \mathrm{kg}$ ME içeren buzağ başlangıç yemi 7. günden itibaren buzağılara ad libitum düzeyde verilmeye başlanmıştır. Kullanılan buzağı başlangıç yemine ait besin madde analiz sonuçları tablo1'de sunulmuştur. Yem 7-15. gün 500 gr/gün, 15-30. gün 1000 gr/gün, 30 -45. gün $1500 \mathrm{gr} /$ gün, 45. günden itibaren sütten kesilene kadar ise $2000 \mathrm{gr} /$ gün şeklinde günlük olarak yemliklere konulmuştur.

Buzağıların tüketmediği yemler günlük olarak tartılmak suretiyle alınmış, buzağıların günlük yem tüketimleri hesaplanarak kayıt altına alınmıştır. Yemlerin tartım işlemleri 5 gr hassasiyeti olan $40 \mathrm{~kg}$ kapasiteli elektronik terazi kullanılarak gerçekleştirilmiştir. Bütün buzağıların doğum, 15, 30, 45 ve 60 . günlerinde 50 gram hassasiyetli 1000 kg kapasiteli hayvan kantarı kullanılarak tartımları yapılmış ve kayıt altına alınmıştır. 60. gündeki tespit edilen canlı ağırlık aynı zamanda sütten kesim ağırlığı (SKA) olarak kayıt altına alınmıştır. Buzağıların sağlık durumları deneme boyunca günlük takip edilmiş olup, özellikle ishal olan buzağılar tespit edilip kayıt altına alınmış ve süreç boyunca takip dilmiștir. İshal olan buzağılara standart olarak Baytril K \%2.5 (Her ml sinde 25 mg Enrofloksasin içerir) ticari preparattan $2 \mathrm{ml}$ IM olarak 3 gün, Fulimed ( Her ml sinde $50 \mathrm{mg}$ Fluniksin Meglumin içerir) ticari preparattan $2 \mathrm{ml}$ IM olarak 3 gün uygulanmak suretiyle tedavileri gerçekleștirilmiştir. 
Denemede kullanılan yem örneklerin kuru madde (KM), ham kül (HK), organik madde (OM), ve ham protein (HP) içerikleri AOAC (1990) analiz sistemine, nötral deterjan fiber (NDF), Van Soest ve Robertson (1979)'a göre, asit deterjan fiber (ADF) ise Goering ve Van Soest (1970)'e göre belirlenmiștir. Deneme sonunda bütün buzağllardan EDTA'lı tüplere kan alınarak hızlı bir şekilde Kırıkkale Üniversitesi Veteriner Fakültesi Biyokimya laboratuvarına ulaştırılmış ve bu kan örneklerinde kan hücre sayımı yapılmıştır. Denemede elde edilen veriler SAS istatistik programı kullanılarak variyans analizine tabi tutulmuş (SAS 1995) ve ortalamalar arasındaki farklılıklar ise Duncan testi ile belirlenmiştir (Steel ve Torie 1980).

\section{BULGULAR}

Çalışmada kullanılan buzağı başlangıç yeminin besin madde içeriğine ilişkin veriler tablo 1'de, buzağıların canlı ağrılılarına ait veriler Tablo 2'de, günlük canlı ağırlık artışı ve denede süresince toplan canlı ağırlık artışların ilişkin veriler Tablo 3'de sunulmuștur.
Çalıșmada kullanılan buzağıların deneme süresince toplam yem tüketim verileri Tablo 4'de, ortalama günlük yem tüketim verileri Tablo 5 ve yemden yaralanma değerleri ise Tablo 6'da gösterilmiştir. Denemede kullanılan buzağılardan deneme sonunda alınan kan parametrelerine ait veriler Tablo 7 'de, deneme süresince ishal görülme oranına ilişkin rakamlar ise Tablo 8'de sunulmuştur.

Tablo 1. Buzağılara verilen buzağı başlangıç yeminin besin madde içeriği, (\% KM'de).

Table 1. Nutrient composition of calf starter feed fed to calves, (DM\%).

\begin{tabular}{lc}
\hline KM & 93.06 \\
Kül & 7.34 \\
OM & 92.66 \\
NDF & 23.55 \\
ADF & 5.19 \\
CP & 19.26 \\
\hline
\end{tabular}

Tablo 2. Denemede kullanılan buzağıların deneme süresince canlı ağırlık verileri, kg.

Table 2. Live weight values of calves used in the experiment throughout the experiment, kg.

\begin{tabular}{lllll}
\hline Canlı Ağırlık & Kontrol & DCMK & YCMK & P \\
\hline Doğum Ağırlığı & $41.58 \pm 2.16$ & $42.42 \pm 1.61$ & $41.17 \pm 3.24$ & 0.72 \\
15. Gün & $46.42 \pm 1.83$ & $46.33 \pm 1.67$ & $45.75 \pm 2.69$ & 0.78 \\
30. Gün & $57.58 \pm 2.35$ & $58.50 \pm 2.31$ & $57.67 \pm 3.04$ & 0.74 \\
45. Gün & $69.75 \pm 1.67$ & $70.92 \pm 2.15$ & $73.00 \pm 2.29$ & 0.13 \\
60. Gün & $81.50 \pm 3.11$ & $84.58 \pm 3.17$ & $85.58 \pm 3.59$ & 0.14 \\
\hline
\end{tabular}

Tablo 3. Denemede kullanılan buzağıların deneme süresince günlük ve toplam canlı ağırlık artış verileri, kg.

Table 3. Daily and total live weight gains of calves used in the experiment throughout the experiment, $\mathrm{kg}$.

\begin{tabular}{lllll}
\hline Canlı Ağırlık Artışı, kg/g & Kontrol & DCMK & YCMK & P \\
\hline 0-15. Gün & $0.26 \pm 0.04$ & $0.32 \pm 0.03$ & $0.31 \pm 0.05$ & 0.59 \\
0-30. Gün & $0.53 \pm 0.04$ & $0.54 \pm 0.04$ & $0.55 \pm 0.02$ & 0.94 \\
0-45. Gün & $0.63 \pm 0.03$ & $0.63 \pm 0.03$ & $0.71 \pm 0.05$ & 0.24 \\
0-60. Gün & $0.67 \pm 0.03$ & $0.70 \pm 0.04$ & $0.74 \pm 0.03$ & 0.31 \\
0-90. Gün* & $0.74 \pm 0.09$ & $0.81 \pm 0.08$ & $0.79 \pm 0.06$ & 0.82 \\
15-30. Gün & $0.81 \pm 0.15$ & $0.83 \pm 0.05$ & $1.02 \pm 0.15$ & 0.31 \\
30-45. Gün & $0.78 \pm 0.16$ & $0.91 \pm 0.11$ & $0.84 \pm 0.11$ & 0.44 \\
45-60. Gün & $0.67 \pm 0.03$ & $0.70 \pm 0.04$ & $0.74 \pm 0.03$ & 0.78 \\
Toplam Canlı Ağırlık Artışı, kg & $39.92 \pm 1.87$ & $42.17 \pm 2.15$ & $44.42 \pm 1.99$ & 0.31 \\
\hline
\end{tabular}

*İstatistiksel tahmini değerlerdir

Tablo 4. Denemede kullanılan buzağıların deneme süresince toplam yem tüketim verileri, gr.

Table 4. Total feed intake values of calves used in the experiment throughout the experiment, gr.

\begin{tabular}{lllll}
\hline Toplam Yem Tüketimi, gr & Kontrol & DCMK & YCMK & P \\
\hline 0-15. Gün & $715.83 \pm 141.54$ & $526.67 \pm 75.21$ & $644.17 \pm 168.47$ & 0.61 \\
15-30. Gün & $2776.67 \pm 618.24$ & $2842.50 \pm 480.32$ & $2847.50 \pm 516.89$ & 0.99 \\
30-45. Gün & $3901.67 \pm 570.67$ & $4431.67 \pm 654.20$ & $4154.17 \pm 663.48$ & 0.84 \\
45-60. Gün & $9541.67 \pm 1107.79$ & $10238.33 \pm 1310.42$ & $7595.00 \pm 1237.60$ & 0.31 \\
0-60. Gün & $16935.83 \pm 2226.32$ & $18039.17 \pm 2405.41$ & $15240.83 \pm 2152.58$ & 0.68 \\
\hline
\end{tabular}


Tablo 5. Denemede kullanılan buzağıların deneme süresince günlük yem tüketim verileri, gr/gün.

Table 5. Daily feed intake values of calves used in the experiment throughout the experiment, gr/d.

\begin{tabular}{lllll}
\hline Günlük Yem Tüketimi & Kontrol & DCMK & YCMK & P \\
\hline 0-15. Gün & $47.72 \pm 9.44$ & $35.11 \pm 5.01$ & $42.94 \pm 11.23$ & 0.61 \\
15-30. Gün & $185.11 \pm 41.22$ & $189.50 \pm 32.02$ & $189.83 \pm 34.46$ & 0.99 \\
30-45. Gün & $260.11 \pm 38.04$ & $295.44 \pm 43.61$ & $276.94 \pm 44.23$ & 0.84 \\
45-60. Gün & $636.11 \pm 73.85$ & $682.56 \pm 87.36$ & $506.33 \pm 82.51$ & 0.31 \\
0-60. Gün & $282.26 \pm 37.11$ & $300.65 \pm 40.09$ & $254.01 \pm 35.88$ & 0.68 \\
\hline
\end{tabular}

Tablo 6. Denemede kullanılan buzağıların deneme süresince yemden yararlanma verileri, gr yem/kg CAA.

Table 6. Feed efficiency values of calves used in the experiment throughout the experiment, gr yem $/ \mathrm{kg}$ LWG.

\begin{tabular}{lllll}
\hline Yemden Yararlanma gr/kg CAA & Kontrol & DCMK & YCMK & P \\
\hline 0-15. Gün & $158.82 \pm 39.89$ & $140.58 \pm 14.90$ & $177.67 \pm 66.84$ & 0.85 \\
15-30. Gün & $249.10 \pm 45.88$ & $235.23 \pm 34.16$ & $242.37 \pm 37.58$ & 0.97 \\
30-45. Gün & $420.46 \pm 116.88$ & $361.55 \pm 56.15$ & $300.52 \pm 58.00$ & 0.60 \\
45-60. Gün & $1180.06 \pm 431.57$ & $748.44 \pm 29.09$ & $640.04 \pm 122.47$ & 0.32 \\
0-60. Gün & $418.89 \pm 40.42$ & $419.44 \pm 36.88$ & $342.93 \pm 47.57$ & 0.36 \\
\hline
\end{tabular}

Tablo 7. Denemede kullanılan buzağıların deneme sonu kan parametreleri.

Table 7. Blood parameter of calves used in the experiment at the end of the experiment.

\begin{tabular}{|c|c|c|c|c|}
\hline & Kontrol & DCMK & YCMK & $\mathbf{P}$ \\
\hline WBC & $8.47 \pm 0.67$ & $8.56 \pm 0.51$ & $9.29 \pm 0.57$ & 0.57 \\
\hline LYM & $5.62 \pm 0.45$ & $5.45 \pm 0.26$ & $5.35 \pm 0.15$ & 0.83 \\
\hline MON & $0.26 \pm 0.13$ & $0.17 \pm 0.04$ & $0.19 \pm 0.04$ & 0.71 \\
\hline NEU & $2.40 \pm 0.41$ & $2.72 \pm 0.31$ & $3.38 \pm 0.46$ & 0.25 \\
\hline EOS & $0.33 \pm 0.06$ & $0.30 \pm 0.05$ & $0.36 \pm 0.01$ & 0.71 \\
\hline BAS & $0.02 \pm 0.00$ & $0.02 \pm 0.00$ & $0.02 \pm 0.00$ & 0.90 \\
\hline LY\% & $65.58 \pm 1.90$ & $63.50 \pm 2.14$ & $58.43 \pm 2.97$ & 0.06 \\
\hline MO\% & $2.70 \pm 1.30$ & $1.82 \pm 0.34$ & $2.02 \pm 0.34$ & 0.72 \\
\hline NE\% & $27.47 \pm 2.68$ & $31.00 \pm 1.84$ & $35.42 \pm 3.15$ & 0.05 \\
\hline EO\% & $4.02 \pm 0.94$ & $3.47 \pm 0.58$ & $3.95 \pm 0.40$ & 0.82 \\
\hline BA $\%$ & $0.20 \pm 0.05$ & $0.18 \pm 0.03$ & $0.18 \pm 0.03$ & 0.94 \\
\hline $\mathrm{RBC}$ & $9.61 \pm 0.38$ & $9.98 \pm 0.50$ & $9.79 \pm 0.39$ & 0.83 \\
\hline HGB & $8.48 \pm 0.33$ & $9.23 \pm 0.46$ & $8.85 \pm 0.27$ & 0.37 \\
\hline HCT & $25.86 \pm 1.05$ & $27.97 \pm 1.18$ & $27.18 \pm 0.97$ & 0.39 \\
\hline MCV & $27.00 \pm 0.86$ & $28.17 \pm 0.75$ & $27.83 \pm 1.08$ & 0.65 \\
\hline $\mathrm{MCH}$ & $8.85 \pm 0.25$ & $9.28 \pm 0.22$ & $9.08 \pm 0.27$ & 0.49 \\
\hline $\mathrm{MCHC}$ & $32.73 \pm 0.46$ & $32.97 \pm 0.35$ & $32.57 \pm 0.35$ & 0.77 \\
\hline RDWc & $30.80 \pm 1.35$ & $28.40 \pm 0.74$ & $30.03 \pm 1.71$ & 0.45 \\
\hline PLT & $582.67 \pm 42.85$ & $580.50 \pm 62.09$ & $512.33 \pm 41.57$ & 0.54 \\
\hline PCT & $0.30 \pm 0.02$ & $0.33 \pm 0.05$ & $0.27 \pm 0.03$ & 0.46 \\
\hline MPV & $5.08 \pm 0.10$ & $5.58 \pm 0.20$ & $5.13 \pm 0.13$ & 0.06 \\
\hline PDWc & $29.08 \pm 0.96$ & $31.40 \pm 0.94$ & $29.40 \pm 1.38$ & 0.31 \\
\hline
\end{tabular}

Tablo 8. Buzağıların İshale yakalanma \% oranları.

Table 8. Diarrhea prevalence of calves used in the experiment throughout the experiment, \%.

\begin{tabular}{llll}
\hline Grup & Toplam Hayvan Sayısı & İshale Yakalanan Hayvan Sayısı & İshal Olma Yüzdesi \\
\hline K & 6 & 5 & 83.33 \\
DCMK & 6 & 4 & 66.67 \\
YCMK & 6 & 2 & 33.33 \\
\hline
\end{tabular}




\section{TARTIŞMA ve SONUÇ}

Süt emme dönemindeki Simental ırkı buzağılara farlı miktarlarda canlı maya kültürü olarak verilen Saccharomyces cerevisiae'nin buzağı performans ve sağlığı üzerine etkilerini araştırıldığı bu çalışmada, buzağıların canlı ağırlık verileri Tablo 2'de verilmiștir. Söz konusu tablo incelendiğinde, denemeye alınan buzağıların doğum ağılıkları birbirine yakın olup, istatistiksel ve kayda değer rakamsal farklılığın olmadığı görülmüştür. 15 ve 30 . günlerde yapılan ölçümlerde canlı ağırlık artışları birbirine yakın iken, 45. günden itibaren canlı maya kültürüli gruplarda istatistiksel olarak farlı olmamakla birlikte rakamsal canlı ağırlık artışı olduğu görülmüştür. Sütten kesme yaşı olan 60. güne gelindiğinde DDG $84.58 \mathrm{~kg}$, YDG $85.58 \mathrm{~kg}$ ve KG 81.50 kg olarak ölçümleri gerçekleşmiştir. Çalışma sonunda DDG nin KG ye göre yaklașık $3 \mathrm{~kg}$, YDG ise $\mathrm{KG}^{\prime}$ a göre $4 \mathrm{~kg}$ daha fazla canlı ağırlık aldığı tespit edilmiştir. Diler ve Aydın (2009) İsviçre Esmeri buzağılarla yaptığı benzer bir çalışmada buzağıların doğum ağırlıklarının yaklașık $39 \mathrm{~kg}$ ve 8 hafta sonunda sütten kesim ağırlıklarının ise kontrol grubu $67.8 \mathrm{~kg}$ canlı maya kültürü tüketen grubun ise $72.0 \mathrm{~kg}$ olduğunu ve gruplar arasına yaklaşık $4 \mathrm{~kg}$ fark olmasına rağmen farlılı̆̆ın istatistiksel olarak öneli bulunmadığı bildirilmiștir. Yine, Işık ve ark. (2004)'de Holştayn buzağılarla yaptığ çalışmada, buzağıların doğum ağrılıklarının $34.0-39.8 \mathrm{~kg}$, 2 ay sonunda ise canlı ağırlıklarının 64.0-72.0 kg aralığında olduğu, canlı maya kültürü verilen grubun canlı ağırlıklarının daha fazla olmasına karşın istatistiksel olarak benzer bulunduğu ifade edilmiştir. Söz konusu çalışmadaki buzağıların gerek doğum ve gerekse 60 gün sonunda sütten kesim ağırlıkları yukarıda bahsedilen çalışmalardan daha yüksek olmakla birlikte, canlı maya kültürü kullanımının etkisi her iki çalışma sonuçlarıyla benzerlik göstermektedir. Canlı ağırlıkların farklı oluşu kullanılan ırkların yapılarıyla ilgili olduğu düşünülmektedir.

Canlı ağırlık artışları değerlendirildiğinde 0-15., 0-30. ve 045. günler de gruplardaki canlı ağırlık artışlarının istatistiksel olarak önem arz etmediği görülmüştür. Günlük canlı ağırlık artışının 0-60. Günler arasında DDG $0.70 \mathrm{~kg} / \mathrm{g}$, YDG $0.74 \mathrm{~kg} / \mathrm{g}$ ve KG $0.67 \mathrm{~kg} / \mathrm{g}$ olarak hesaplanmıştır. YDG nin DDG ve KG ye göre, DDG'nin de KG'ye göre daha fazla günlük canlı ağırlık artışı sağladığı görülmüştür. Altmış günlük deneme sonunda, toplam canlı ağırlık artışı DDG $42.17 \mathrm{~kg}$, YDG $44.42 \mathrm{~kg}$ ve $\mathrm{KG} 39.92 \mathrm{~kg}$ olarak belirlenmiştir. YDG nin KG'ye göre yaklaşık $4.5 \mathrm{~kg}$ ve DDG'ye göre ise $2 \mathrm{~kg}$ daha fazla canlı ağırlık artışı olduğu, DDG nin ise KG ye göre $2.2 \mathrm{~kg}$ 'lık daha fazla canlı ağırlık artışı kazandığı görülmüştür. Bu kazanılan canlık ağırlıklar oransal olarak ele alındığında YDG'nin KG'ye göre \%11.27, DDG'nin KG'ye göre ise \%5.51daha fazla canlı ağırlık arışı sağlandığı görülmektedir. Diler ve Aydın (2009) İsviçre Esmeri buză̆ılarda 8 haftalık ortalama günlük canlı ağırlık artıșının canlı maya kültürü grubunda $0.569 \mathrm{~kg}$, kontrol grubunda $0.523 \mathrm{~kg}$ olup proiyotik grubunun, kontrol grubuna göre sırasıyla $\% 6.2$ ve $\% 8.9$ daha fazla üstünlük sağlamış olmasına karşın aradaki farklılık istatistiksel olarak önemli bulunamadığını ifade etmiştir. Yine Gill ve ark. (1987) 307 buzağıya 28 gün süre ile canlı maya kültürü verdiği denemede ortalama günlük canlı ağırlık artışının \%9.3 daha fazla olduğunu ifade etmiştir. Mevcut çalışmada günlük canlı ağırlık artışlarının doz artışına paralel olarak \%5.51 ile \%11.21 düzeyinde artırdığ saptanmıștır. Jatkauskas ve Vrotniakiene (2010) Litvanya Alacası buzağılarla yaptığı bir çalışmada, 62 günlük deneme süresinde kontrol grubundaki buzağılar 40.1 kg toplam canlı ağrılık kazanırken probiyoik tüketen buzağıların $47.9 \mathrm{~kg}$ canlı ağırlık kazandığını ve farklılığın istatistikselde önemli bulunduğu ifade etmişlerdir. $\mathrm{Bu}$ sonuçlar literatür verileriyle uyum içindedir.

Denemede kullanılan buzağıların toplam yem tüketimleri; 0-15, 15-30, 30-45 ve 45-60. günler aralıklarındaki yem tüketimlerinin dönemsel olarak rakamsal farklılıklar arz ettiği ancak bu sayısal farklılıkların istatistiki açıdan önemli olmadığı görülmüștür. 0-60. günler arasında yani tüm deneme süresi boyunca toplam yem tüketimi DDG 18039.17gr, YDG 15240.83 gr ve KG 16935.83 gr olarak ölçülmüş ve bu veriler incelendiğinde YDG nin DDG ye göre yaklaşık $3 \mathrm{~kg}$ KG'ye göre ise $1.5 \mathrm{~kg}$ daha az yem tüketmesine rağmen daha fazla canlı ağırlık artışı kazandığı belirlenmiștir. Günlük ortalama yem tüketimleri 0-15., 15-30., 30-45. günler de ölçülen günlük yem tüketimleri gruplar bazında birbirine yakın, 45-60. arasında DDG nin en fazla günlük yem tüketimine sahip olduğu YDG'nin KG'den $130 \mathrm{gr} /$ gün DDG den ise 174 gr/gün daha az yem tükettiği görülmüştür. Deneme süresi boyunca ortalama günlük ortalama yem tüketimleri ise DDG 300.65 gr/gün, YDG 254,01 gr/gün ve KG 282.26 gr/gün olarak belirlenmiștir. Söz konusu veriler incelendiğinde DDG'nin KG'ye göre yaklaşık $18 \mathrm{gr} /$ gün fazla olduğu, YDG'nin ise KG'ye göre $28 \mathrm{gr} / g u ̈ n$ az olduğu görülmüștür. Işılk ve ark. (2004) da Holştayn buzağıların ikinci ayda ortalama 615-759 gr/gün yem tükettiklerini ifade etmiștir. Söz konusu çalışmada, 0-60 günler ortalaması 300 gr civarında olup çok düşüktür. Ancak, 4560. günler arası ortalama yem tüketim değerleri Işık ve ark. (2004) bildirdiği değerlerle uyum içinde olduğu görülmektedir. Mevcut çalışma sonuçlarına benzer olarak, yapılan çalıșmalarda canlı maya kültürü kullanımının yem tüketimi üzerine önemli bir etkisinin olmadığını ifade edilmiştir Gill ve ark. 1987; Diler ve Aydın 2009)

Yemden yararlanma verilerine göre KG 45-60. günler arasında 1 kg canlı ağırlık artıșı sağlamak için 1180 gr yem tükettiği KG ye göre DDG nin 432 gr, YDG nin ise 540 gr daha az yem tükettiği hesaplanmıştır. $0-15,15-30$ ve 30 45. günlerde sayısal farklılıkların oluştuğu ancak bu farklılıkların istatistiki açıdan önemli olmadığı görülmüştür. Deneme süresi boyunca ortalama yemden yararlanma değerleri ise DDG 419.44 gr yem/kg CAA., YDG 342.93 gr yem/kg CAA. ve KG 418.89 gr yem $/ \mathrm{kg}$ CAA olarak belirlenmiștir. KG ve DDG arasında yemden yararlanma açısından farklılık görülmeyip YDG nin $1 \mathrm{~kg}$ canlı ağırlık artışı için her iki gruba göre yaklaşık 80 gr daha az yem tükettiği görülmüştür. Buda yaklaşı olarak $\% 19.05$ 'lik daha az bir yem tüketimi anlamına gelmektedir. Işık ve ark. (2004) yapmış olduğu bir çalışmada canlı maya kültürü kullanımının buzağılarda yemden yaralanma değerini \%11.05 oranında iyileştirdiği ifade edilmiştir. Yine benzer şekilde canlı maya kültürü kullanımının yemden yararlanmayı \%5.6 (Hooper 1990) ve \%9.5 (Gill ve ark. 1987) iyileștiğini bildiren çalıșmalar mevcuttur. Mevcut çalışmada canlı maya kültürülerin etkisi literatür bildirimleriyle uyumlu olmakla birlikte istatistiksel fark tespit edilememiştir. Bunun en önemli sebebi mevcut çalışmada kullanılan buzağı sayısının biraz az oluşundan kaynaklandığı düşünmektedir. Canlı maya kültürü kullanımının yararlarını gösteren birçok çalıșmanın olmasına kașın, canlı maya kültürü kullanımının buzağılarda istatistiksel olarak önemli bir etkisinin tespit edilemediğini bildiren çalışmalar da bulunmaktadır (Alp ve Kahraman 1996). Bu tür birbirinden farklı sonuçların ortaya çıkışı; kullanılan canlı maya kültürülerin farklılığı, denemde kullanan hayvanların ırk-yaş-cinsiyet farklılığı, farklı çevre şartları 
ve uygulanan bakım-besleme programlarına kadar değișik birçok faktörün etkili olabileceğini göz önünde bulundurulmalıdır.

Kan analiz sonuçları değerlendirildiğinde tam kan parametrelerinin tüm gruplarda referans değer aralıklarında olduğu ve bu değerlerin istatistiksel açıdan önem arz eden farlılıklar olmadığı görülmüștür. Kan hücrelerinden lenfosit oranı katılan katkı oranına paralel olarak azalıkken nötrofil oranının $(\mathrm{P}=0.05)$ ise lineer olarak artış gösterdiği saptanmıștır. Buda, NE\% ve LY\% nin $(P=0.05)$ istatistiksel öneme yakınlığından dolayı canlı maya kültürü tüketiminin immun sistem üzerine etkisi olabileceğini düşündürmektedir.

Denemede kullanılan buzağılar arasında hiçbir ölüm görülmemiştir. Deneme süreci boyunca DDG den 4 adet, YDG den 2 adet KG den 5 adet buzağı ishal olmuștur. Hayvan sayılarına oranlandığı da isal görülme oranı KG'da \%83.33, DDG'da \%66.67 ve YDG'da ise \%33.33 olarak hesaplamıştır. Buda canlı maya kültürü kullanımının buzağılarda isal görülme sıklığını ciddi anlamda azalttığını göstermektedir. Yapılan çalıșmalar, buzağılarda canlı maya kültürü kullanımının ishal vakalarını önlediği ve ishal olma sıklığını azalttığını ortaya koyduğu görülmemektedir (Gill ve ark. 1987; Abe ve ark. 1995; Ișık ve ark. 2005; Aydın ve ark. 2008; Diler ve Aydın 2009).

Sonuç olarak, süt buzağılarına verilen mayanın istatistiksel olarak olmasa da canlı ağırlık artışı, yemden yaralanmayı, buzağı sağlığını iyileștirdiği ve immum sistem üzerine de olumlu etkisi olabileceği kanaati oluşmuştur. Kullanılan mayanın daha fazla buzağı kullanılarak daha detaylı olarak etkilerinin araştırılmasının faydalı olacağı düşünülmüştür.

\section{KAYNAKLAR}

Abe F, Ishibashi N, Shimamura S (1995). Effect of administration o Bifidobacteria and lactic acid bacteria to newborn calves and piglets. $J$ Dairy Sci, 78, 2838-2846.
Alp M, Kahraman R (1996). Canlı maya kültürülerin hayvan beslemede kullanılması. İst Üniv Vet Fak Derg, 22(1), 1-8.

Anonim ( 2016). Hayvancllk akademisi.http://hayvancilikakademisi.com/ hayvancilik/surulerdeki-en-onemli-sinirlandirici-etken-buzagiolumleri. Erișim Tarihi: 01.08.2016.

AOAC (1990). Association of Official Analitical Chemists. Official Methods of Analysis. 15th Ed., Washington, DC.

Aydin R, Diler A, Yanar M, Kocyigit R, Ozkilicci T (2008). The effect of direct fed microbials plus enzymes supplement on the growth performance of Holstein Friesian calves. J Anim and Vet Adv, 7(4), 516519.

Diler A, Aydın R (2009). Rasyona canlı maya kültürü - enzim kombinasyonu ilavesinin İsviçre esmeri rrkı buzağılarda büyüme performansı ve yemden yararlanma ve sağlık üzerine etkileri. Hayvansal Üretim, 50(2), 22-28.

Gill DR, Smith RA, Ball RL (1987). The effect of probiotics feeding on health and performance of newly arrived stocker calves. Anim Sci Res Rep, 119, 202-204.

Goering HK, Van Soest PJ (1970). Forage Fiber Analyses. Apparatus, Reagent, Procedures and Applications. USDA Agric. Handbook No.379.

Ișık M, Ekimler F, Özen N, Fırat MZ (2004). Canlı maya kültürü kullanmanın buzağı büyüme performansı ve sağlığı üzerine etkileri. Turk J Vet Anim Sci, 28(1), 63-69.

Jatkauskas J, Vrotniakiene V ( 2010). Effects of probiotic dietary supplementation on diarrhoea patterns, faecal microbiota and performance of early weaned calves. Veterinarni Medicina, 55(10), 494-503.

SAS (1995). Statistical Analysis Software, Programme User Guide. Statistics 5 ed., SAS Inst., Inc. Carry, NC

Saygıcı A, Günal M (2004). Farklı düzeylerde protein içeren yumurta tavuğu rasyonlarına canlı maya kültürü ilavesinin performans ve bazı yumurta kriterleri üzerine etkileri. Ulusal Zootekni Bilim Kongresi, Isparta.

Steel RG, Torrie JH (1980). Principle and Procedures of Statistics. 2. ed., Mc Donald book Co., Inc., New York, NY.

Şahal M, Ceylan E, Terzi OS, Kara E (2017). Buzağı ishalleri ve korunma yöntemleri. Buzağı Kayıplar Sempozyumu, Kırıkkale, s. 51.

Van Soest PJ, Robertson JB (1979). Systems Of Analyses For Evaluation Of Fibrous Feed. In, Pigden WJ, Balch CC And Graham M (Eds.): Proc. Int. Workshop On Standardization of Analytical Methodology For Feeds. Int. Dev. Res. Center, Ottowa, Canada, pp. 49-60. 